\title{
The Effect Of Gadgets On The Development Of Youth In Genteng Banyuwangi
}

\author{
Harwanti Noviandari ${ }^{1}$, Agus Mursidi², Eko Listiwikono ${ }^{3}$ \\ 1,2Faculty Of Teaching And Education, PGRI Banyuwangi University \\ ${ }_{3}^{3}$ Mathematics Education, Faculty Of MIPA, PGRI Banyuwangi University \\ Email: 1harwantinoviandari@gmail.com, 2agusmursidi78@gmail.com

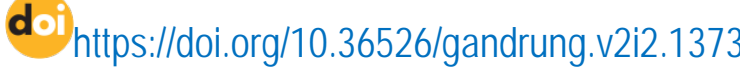

\begin{abstract}
Teenagers are facilitated in accessing the world of information and have a lot of influence on human life and child development. The use of gadgets has a positive impact on human life, but if used excessively it will have a negative impact, especially for children. The positive impact of using gadgets for children, including in the mindset of children, namely: being able to help children in regulating the speed of their play, processing strategies in games, and helping to improve the ability of the child's right brain while under good supervision. On the other hand, the negative impacts of using gadgets for children include: children become difficult to socialize, unstable in emotional control, slow in motor development, the emergence of a sense of laziness, waste, significant behavioral changes to changes in academic achievement at school. The target audience of this service activity are PKK Korsda women at the Banyuwangi Tile Irrigation Service. The women of PKK Korsda of the Banyuwangi Tile Irrigation Service became the target audience because there was a request from the head of the PKK Korsda of the Banyuwangi Irrigation Service at the Banyuwangi PGRI University who needed resource persons in the activities of the PKK Korsda women of the Tile Irrigation Service. The activity is carried out every month, so that the service activities carried out by the PGRI Banyuwangi University service team are adjusted to the needs.
\end{abstract}

Keyword: Development Of Youth, Effect Of Gadgets, Genteng Banyuwangi

\section{Pendahuluan}

Proses masuknya gadget di kalangan remaja dapat dilihat dari berbagai faktor, saat ini perkembangan dunia teknologi peranti lunak (software) sudah menembus sampai ke tingkat pedesaan, hal ini merupakan sebuah kemajuan khususnya di bidang Teknlogi Informasi. Remaja dimudahkan dalam mengakses dunia informasi dan memberikan pengaruh banyak ke dalam kehidupan manusia serta perkembangan anak (Noviandari \& Kawakib, 2016). Gadget bukan hanya dijadikan pembantu kehidupan ataupun alat komunikasi dengan dunia luar, tapi juga bisa dijadikan teman untuk mengisi waktu luang, seperti penggunaan internet, bermain game, mendengar musik atau radio, menyimpan kenangan lewat foto, video. Hal tersebut membuat kehawatiran bagi kalangan ibu-ibu khusunya di PKK di korda pengairan kecamatan Genteng

Kemajuan dan kemutakhiran teknologi turut mengikuti setiap laju perkembangan zaman yang berdampak pada perubahan gaya hidup hingga bidang pendidikan. Perubahan gaya hidup anak di 
sekolah berubah dari tahun ke tahun. Proses belajar mengajar di dalam zaman sekarang sangat membutuhkan teknologi, semua akses internet dapat membantu para siswa untuk mengerjakan tugas. Selain untuk mengerjakan tugas, bermain game juga sangat diperlukan karena untuk refreshing dan untuk hiburan setelah mengerjakan tugas. Gadget juga diperlukan dalam bidang komunikasi, komunikasi zaman sekarang juga diperlukan karena zaman sekarang bila tidak adanya alat komunikasi seperti Handphone akan sangat ketinggalan zaman dan tidak dapat berkomunikasi dengan keluarga, teman dan pacar, untuk itulah siswa dan siswi usia remaja sangat ketergantungan pada gadgetkarena sangat dibutuhkan ((Frambach et al., 2014). Namun ketergantungan mereka terhadap gadget sebenarnya tidak bagus untuk kehidupannya. disaat anak tumbuh dewasa.

Pemakaian Gadget memiliki dampak positif bagi kehidupan umat manusia, namun jika digunakan secara berlebihan justru menimbulkan dampak negatif khususnya bagi remaja. Dampak positif pemakaian gadget bagi anak, diantaranya dalam pola pikir anak yaitu: mampu membantu anak dalam mengatur kecepatan bermainnya, mengolah strategi dalam permainan, dan membantu meningkatkan kemampuan otak kanan anak selama dalam pengawasan yang baik. Sedangkan sebaliknya dampak negatif pemakaian gadget bagi anak, diantaranya: anak menjadi sulit bersosialisasi, labil dalam pengendalian emosi, lamban dalam perkembangan motorik, timbulnya rasa malas, pemborosan, terjadi perubahan perilaku yang signifikan hingga perubahan prestasi akademik di sekolah.

Berdasarkan kondisi di lingkungan sekitar dan pengalaman yang dirsakan oleh orang tua (khususnya Ibu), sehingga ibu-ibu PKK Korsda Pengairan Genteng meminta tim pengabdian masyarakat Universitas PGRI untuk melakukan kegiatan parenting bagi ibu-ibu PKK Korsda Pengairan Genteng, Kabupaten Banyuwangi.

\section{Pengertian Gadget}

Gadget adalah sebuah perangkat yang dirancang dengan tujuan dan fungsi yang praktis yang dibuat dengan kecanggihan tinggi atau lebih canggih dari teknologi sebelumnya(Jacob \& Scott-Phillips, 2020). Pada dasarnya, Gadget merupakan perangkat berlayar dengan teknologi canggih. Gadget adalah sebuah istilah dalam bahasa Inggris yang mengartikan sebuah alat elektronik kecil dengan berbagai macam fungsi khusus(Hikmaturrahmah, 2020). Gadget sebagai benda dengan karakteristik unik, memiliki sebuah unit dengan kinerja yang tinggi dan berhubungan dengan ukuran serta biaya(Rahmawati, 2020). Salah satu hal yang membedakan gadget dengan perangkat elektronik lainnya adalah unsur "kebaruan". Artinya, dari hari ke hari gadget selalu muncul dengan menyajikan teknologi terbaru yang membuat hidup manusia menjadi lebih praktis. 


\section{Bahaya Gadget}

Di zaman yang sangat modern pada saat ini perkembangan teknologi terus berkembang. Karena perkembangan teknologi akan berjalan sesuai perkembangan ilmu pengetahuan yang semakin tinggi (Rakhmawati et al., 2020). Teknologi diciptakan untuk memberikan kemudahan bagi kehidupan manusia dalam melakukan aktivitas sehari-hari dan memberikan nilai yang positif (Ariston \& Frahasini, 2018). Namun demikian, walaupun pada awalnya diciptakan untuk menghasilkan manfaat positif, di sisi lain juga memungkinkan digunakan untuk hal negatif. Berikut dampak negatif dari gadget:

a) Lupa waktu

Sebagian besar remaja pelajar telah memanfaatkan kemajuan teknologi dalam penggunaan gadget. Mereka mengisi waktu dengan menggunakan gadget, hampir setiap waktu mereka selalu dengan gadget. Saat belajarpun mereka tidak ingin terlepas dari sang gadget. Mereka tidak memikirkan lagi waktu untuk belajar. Waktu mereka hanyalah dengan gadget, gadget, dan gadget. Tidak hanya waktu untuk belajar yang tersita waktu untuk istirahat, membantu orang tua bahkan sholat sekalipun juga terlupakan.

b) Kurangnya konsentrasi belajar

Penggunaan gadget yang berlebihan dapat menyebabkan menurunnya fokus belajar. Berdasarkan pengamatan di lingkungan sekitar, salah satu bentuk ketidak fokusan siswa-siswi di dalam kelas saat mengikuti pelajaran adalah mengirim teks ke teman sebagai pengalihan yang lebih menggoda banyak siswa-siswi dari pada mendengarkan ceramah atau menyelesaikan tugas kelas. Jika sudah begini konsentrasi untuk belajar pun menurun. Mereka yang seharusnya meluangkan banyak waktu untuk konsentrasi belajar, namun mereka lebih memilih gadget sebagai kesibukan. Jika konsentrasi telah menurun semangat untuk belajar pun hilang.

c) Timbulnya rasa malas

Tidak terlepas dari masalah kurangnya konsentrasi belajar, jika siswa-siswi sudah mengenal kecanggihan gadget pasti menginginkan hal yang praktis. Salah satu contoh, ketika guru memberikan sebuah tugas yang sedikit rumit, banyak dari siswa-siswi langsung membuka internet untuk mengakses jawaban dari soal tersebut. Tanpa di pikirkan terlebih dahulu kebanyakan para siswa-siswi langsung meng copy-paste jawaban yang sudah ada di internet.

d) Efek radiasi

Selain sebagai kontroversi di berbagai dampak negatif gadget, efek radiasi merupakan masalah yang buruk bagi kesehatan. Gadget mengandung zat radio aktif yang mampu berpindah ke suatu zat lain (tubuh manusia) tanpa melalui perantara. Jika pengguna setiap hari setiap waktu tidak pernah 
terlepas dengan gadget bukan tidak mungkin pengguna akan terkena radiasi, kanker otak, mengganggu kesehatan mental, dan kerusakan sel dalam tubuh merupakan efek dari radiasi. Jika sudah terkena efek radiasi pengobatannya pun susah bahkan jika radiasi sudah menyerang seluruh tubuh dan menjadi parah maka dapat menimbulkan masalah yang serius yakni kematian.

e) Pemborosan

Semakin canggih gadget yang siswa-siswi miliki semakin banyak pengeluaran. Apalagi kalau gadget hanya digunakan untuk hal-hal yang tidak bermanfaat maka para siswa-siswi akan menjadi boros. Misalnya, fakta yang ditemukan di lapangan bahwa Rp 50.000 sampai Rp 100.000 per bulan hanya digunakan untuk membiayai gadget. Padahal uang sebesar itu dapat meraka gunakan untuk membeli keperluan sekolah ataupun dapat mereka tabung. Jika para siswa-siswi dari kalangan berada maka uang sebesar itu pun tidak jadi masalah,namun berbeda halnya jika para siswa-siswi yang berasal dari kalangan bawah atau tidak mampu uang sebasar itu sangat penting untuk biaya sekolah daripada biaya gadget.

\section{Perkembangan Remaja}

Masa remaja adalah masa pencarian jati diri dan bisa saja dalam proses pencarian jati diri tersebut para remaja memilih jalan yang benar atau salah, kemajuan teknologi yang berkembang saat ini tidak dapat dipisahkan dari kehidupan masyarakat khususnya di kalangan remaja (Noviandari \& Mursidi, 2019). Pengaruh dari kemajuan teknologi dalam kehidupan remaja adalah hal yang tidak dapat dihindari. Teknologi diciptakan untuk mempermudah setiap kegiatan manusia, namun penambahan fungsi teknologi justru memanjakan manusia khususnya di kalangan remaja.

Efek dari perkembangan teknologi itu sendiri juga dapat kita rasakan dalam kehidupan seharihari. Kemajuan teknologi dapat menambah wawasan remaja, sehingga dapat dengan mudah menemukan informasi-informasi yang penting diketahui oleh pembaca informasi di internet. Dengan adanya informasi yang semakin mudah didapatkan, membuat mudah pula kita mengetahui kejadian yang sangat jauh dari kehidupan kita. Teknologi dapat memberi efek ketergantungan seperti pada media komputer yang memiliki kualitas atraktif yang dapat merespon segala stimulus yang diberikan oleh penggunanya.

\section{Metode}

Khayalak sasaran dari kegiatan pengabdian ini adalah ibu-ibu PKK Korsda Dinas Pengairan Genteng Banyuwangi. Ibu-ibu PKK Korsda Dinas Pengairan Genteng Banyuwangi menjadi khalayak sasaran karena ada permintaan dari ketua PKK Korsda Dinas Pengairan Banyuwangi pada Universitas PGRI Banyuwangi yang membutuhkan narasumber dalam kegiatan Ibu-ibu PKK Korsda Dinas 
Pengairan Genteng. Kegiatan tersebut dilaksanakan setiap bulan, sehingga kegiatan pengabdian dilakukan oleh tim pengabdian Universitas PGRI Banyuwangi disesuaikan dengan kebutuhan, yakni pada hari Selasa, 09 Oktober 2020. Mengadakan parenting atau forum dengan memberikan materi "Bahaya Pengaruh Gadget Terhadap Perkembangan Remaja" Di Korsda Dinas Pengairan Genteng Banyuwangi. Metode yang digunakan dalam kegiatan Pengabdian Kepada Masyarakat adalah sebagai berikut: Mengadakan parenting atau forum dengan memberikan materi "Bahaya Pengaruh Gadget Terhadap Perkembangan Remaja" Di Korsda Dinas Pengairan Genteng Banyuwangi .

Adapun strateginya adalah

1. Ceramah dan tanya jawab mengenai "Bahaya Pengaruh Gadget Terhadap Perkembangan Remaja". Dalam hal ini tim pengabdi memberikan pengertian secara singkat dan sederhana.

2. Pemateri berasal dari latar belakang psikologi, sehingga peserta parenting dapat memahami Bahaya Pengaruh Gadget Terhadap Perkembangan Remaja dari sudut pandang psikologi.

Faktor Penghamat dan Pendukung dalam Kegitan

Dalam pelaksanaan pengabdian, tim pengabdi menemukan beberapa hal yang perlu dicatat sebagai bahan kajian dan renungan bagi kita semua. Hal-hal yang dianggap sebagai pendukung maupun penghambat kegiatan pengabdian, antara lain:

1. Motivasi yang sangat besar dari kalangan ibu-ibu PKK Korsda Dinas Pengairan Genteng Banyuwangi untuk mengetahui Bahaya Pengaruh Gadget Terhadap Perkembangan Remaja dan cara mengatasi serta mengendalikan kondisi tersebut.

2. Sambutan dari ibu-ibu PKK Korsda Dinas Pengairan Genteng Banyuwangi yang amat positif terhadap kegiatan ini sehingga segala koordinasi antara ibu-ibu PKK dan tim pengabdi dapat berjalan dengan baik.

Waktu pelaksanaan yang sangat terbatas, sehingga beberapa pertanyaan yang diberikan oleh Ibu-Ibu PKK belum dapat terjawab dengan baik oleh tim pengabdian masyarakat.

\section{Hasil dan Diskusi}

Secara umum pelaksanaan Pengabdian Masyarakat berjalan dengan lancar sesuai dengan target yang ditetapkan oleh tim pengabdi. Indikatornya dapat dilihat dari beberapa hal antara lain: antusias Ibu-lbu PKK yang begitu besar dalam mengikuti kegiatan pengabdian. Kegiatan pengabdian dilaksanakan selama satu hari yaitu pada hari Selasa, 09 Oktober 2020 bertempat di Kantor Dinas Pengairan Genteng Banyuwangi tampak pada gambar di bawah ini.

Kegiatan pengabdian masyarakat dilaksanakan atas kerjasama antara prodi Bimbingan Dan Konseling Fakultas Keguruan Dan IImu Pendidikan (FKIP) Universitas PGRI Banyuwangi (UNIBA) 
dengan Korsda Pengairan Banyuwangi yang merupakan kegiatan rutin setiap bulan. Indikatornya keberhasilan terlaksananya kegiatan dapat dilihat dari Ibu-Ibu PKK yang begitu besar dalam mengikuti kegiatan pengabdian. Pertanyaan-pertanyaan yang diberikan terkait materi yang diberikan, hingga terbatasnya waktu pelaksanaan membuat semua pertanyaan tidak dapat terjawab oleh pemateri. Permintaan dari ketua PKK Korsda Pengairan Banyuwangi pada pemateri untuk mengisi kembali dalam kegiatan parenting yang diadakan oleh Korsda Banyuwangi di lain waktu. Kegiatan berlangsung dengan baik, lancar, dan tidak menemui hambatan yang berarti.

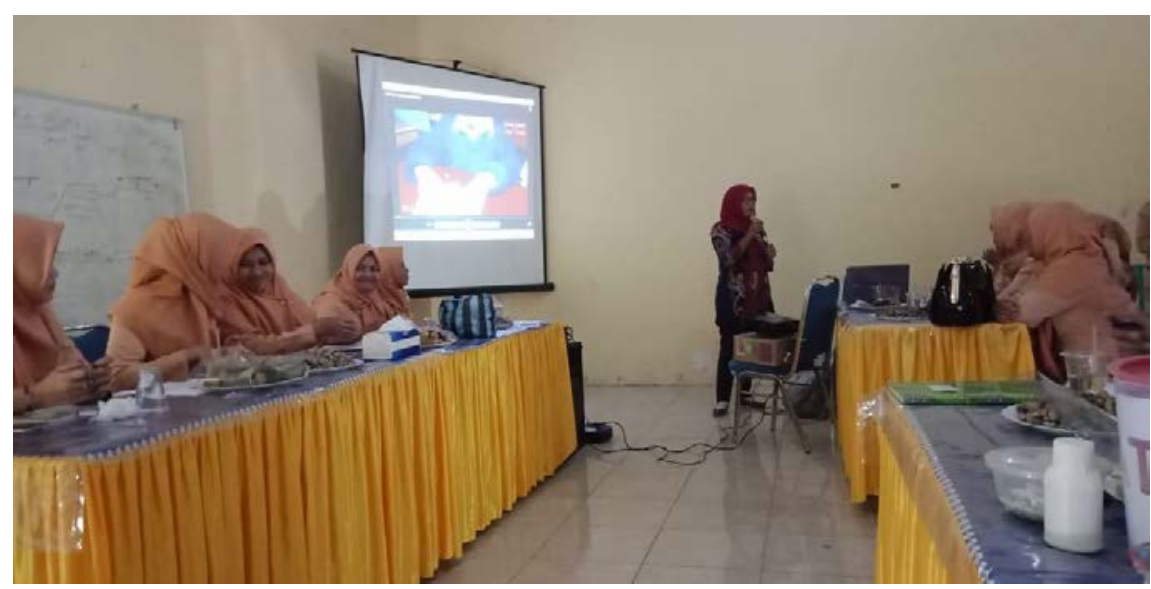

Gambar 1. Parenting "Bahaya Gadget Bagi Perkembangan Remaja"

(Sumber dokumentasi pribadi)

Berdasarkan pelaksanaan pengabdian masyarakat diperoleh hasil, sebagai berikut :

1. Sebagian besar remaja pelajar telah memanfaatkan kemajuan teknologi dalam penggunaan gadget. Mereka mengisi waktu dengan menggunakan gadget, hampir setiap waktu mereka selalu dengan gadget. Saat belajarpun mereka tidak ingin terlepas dari gadget. Tidak hanya waktu untuk belajar yang tersita waktu untuk istirahat, membantu orang tua bahkan sholat sekalipun juga terlupakan. Penggunaan gadget yang berlebihan dapat menyebabkan menurunnya fokus belajar. Mereka yang seharusnya meluangkan banyak waktu untuk konsentrasi belajar, namun mereka lebih memilih gadget sebagai kesibukan. Jika konsentrasi telah menurun semangat untuk belajar pun hilang.

2. Tidak terlepas dari masalah kurangnya konsentrasi belajar, jika siswa-siswi sudah mengenal kecanggihan gadget pasti menginginkan hal yang praktis. Salah satu contoh, ketika guru memberikan sebuah tugas yang sedikit rumit, banyak dari siswa-siswi langsung membuka internet untuk mengakses jawaban dari soal tersebut. Tanpa di pikirkan terlebih dahulu kebanyakan para siswa-siswi langsung meng copy-paste jawaban yang sudah ada di internet. 
3. Efek radiasi merupakan masalah yang buruk bagi kesehatan. Gadget mengandung zat radio aktif yang mampu berpindah ke suatu zat lain (tubuh manusia) tanpa melalui perantara. Jika pengguna setiap hari setiap waktu tidak pernah terlepas dengan gadget bukan tidak mungkin pengguna akan terkena radiasi, kanker otak, mengganggu kesehatan mental, dan kerusakan sel dalam tubuh merupakan efek dari radiasi. Jika sudah terkena efek radiasi pengobatannya pun susah bahkan jika radiasi sudah menyerang seluruh tubuh dan menjadi parah maka dapat menimbulkan masalah yang serius yakni kematian.

4. Penggunaan gadget yang berlebihan juga mengakibatkan pemborosan. Semakin canggih gadget yang siswa-siswi miliki semakin banyak pengeluaran. Apalagi kalau gadget hanya digunakan untuk hal-hal yang tidak bermanfaat maka para siswa-siswi akan menjadi boros. Misalnya, fakta yang ditemukan di lapangan bahwa Rp 50.000 sampai Rp 100.000 per bulan hanya digunakan untuk membiayai gadget. Padahal uang sebesar itu dapat meraka gunakan untuk membeli keperluan sekolah ataupun dapat mereka tabung. Jika para siswa-siswi dari kalangan berada maka uang sebesar itu pun tidak jadi masalah. Namun berbeda halnya jika para siswa-siswi yang berasal dari kalangan bawah atau tidak mampu uang sebasar itu sangat penting untuk biaya sekolah daripada biaya gadget.

Dalam kegitan ini banyak sekali manfaat yang sudah di terima dan di berikan oleh narasumber dan peserta Pertanyaan-pertanyaan yang diberikan terkait materi yang diberikan, hingga terbatasnya waktu pelaksanaan membuat semua pertanyaan tidak dapat terjawab oleh pemateri. Permintaan dari ketua PKK Korsda Pengairan Banyuwangi pada pemateri untuk mengisi kembali dalam kegiatan parenting yang diadakan oleh Korsda Banyuwangi di lain waktu. Kegiatan berlangsung denganbaik, lancar, dan tidak menemui hambatan yang berarti. Keberlangsungan perkembangan anak sama pemahaman tentang tumbuh kembang anak dan peran orang tua didalamnya sangat diperlukan dalam parenting selanjutnya beberapa pembahasan yang menarik adalah sebagai berikut: 


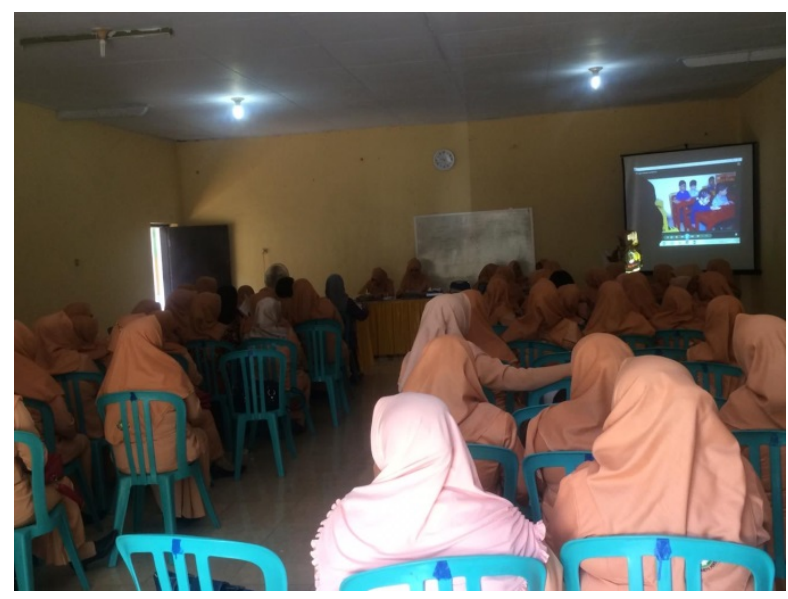

Gambar 2. Kondisi pelaksaan kegiatanPelaksanaan Parenting di Aula Dinas Pengairan Genteng Banyuwangi (sumber dokumen pribadi)

\section{Apa itu Gadget???}

Gadget adalah sebuah perangkat yang dirancang dengan tujuan dan fungsi yang praktis yang dibuat dengan kecanggihan tinggi atau lebih canggih dari teknologi sebelumnya (Chusna, 2017). Pada dasarnya, Gadget merupakan perangkat berlayar dengan teknologi canggih. Sekarang ini pengguna gadget tidak hanya orang dewasa, tetapi semua kalangan termasuk anak dan balita sudah memanfaatkan gadget dalam melakukan aktivitas setiap hari. Pemanfaatan gadget menjadi salah satu jalan pintas orang tua dalam mendampingi anak(Ariston \& Frahasini, 2018). Berbagai fitur dan aplikasi menarik dimanfaatkan untuk menemani anak agar orang tua dapat menjalankan aktivitas dengan tenang, tanpa kwatir anaknya keluyuran, bermain kotor dan berantakin rumah yang akhirnya mengganggu aktivitas orang tua.

Orang tua memberikan keleluasaan pada anak dalam menggunakan gadget, tindakan tersebut dianggap lebih aman dan mudah dalam pengawasan aktivitas buah hati(Marhaeni Pudji Astuti et al., 2018). Ada yang terlupakan dalam pemikiran orang tua, bagaimana pengaruh media teknologi tersebut pada perkembangan anak. Penggunaan gadget berdampak positif jika digunakan tidak secara berlebihan, tetapi jika tidak terkontrol justru dampak negatif yang muncul.

\section{Pengaruh gadget pada perkembangan anak}

Pendidikan dalam keluarga menjadi pondasi karakter anak dalam berperilaku dan bersikap di lingkungan masyarakat. Namun, perkembangan media dan teknologi menjadi tantangan dalam sebuah pendidikan karakter. Perlu diketahui bahwa periode perkembangan anak pada usia 1-5 tahun adalah usia dini yang sering disebut dengan golden age. Pada masa ini, seluruh aspek perkembangan kecerdasan, seperti kecerdasan intelektual, emosi, dan spiritual mengalami perkembangan yang luar biasa sehingga yang akan mempengaruhi dan menentukan perkembangan selanjutnya (Ariston \& 
Frahasini, 2018). Ketika anak di usia golden age, semua informasi akan terserap dengan cepat dan anak menjadi peniru yang handal dan lebih pintar dari yang kita pikir.

Pemakaian Gadget memiliki dampak positif bagi kehidupan umat manusia, namun jika digunakan secara berlebihan justru menimbulkan dampak negatif khususnya bagi anak. Dampak positif pemakaian gadget, antara lain: memperlancar komunikasi, mencerdaskan manusia dengan memperkaya pengetahuan manusia, sarana hiburan. Dampak positif pemakaian gadget bagi anak, diantaranya dalam pola pikir anak yaitu: mampu membantu anak dalam mengatur kecepatan bermainnya, mengolah strategi dalam permainan, dan membantu meningkatkan kemampuan otak kanan anak selama dalam pengawasan yang baik (Marpaung, 2018). Sedangkan sebaliknya dampak negatif pemakaian gadget bagi anak, diantaranya: anak menjadi sulit bersosialisasi, lamban dalam perkembangan motorik, perubahan perilaku yang signifikan. Peran orang tua menjadi berkurang sehingga tergantikan oleh gadget yang menjadi teman bermain. Oleh karena itu, dalam kondisi ini dibutuhkan pemahaman bagi orang tua tentang pengaruh gadget pada anak sehingga dapat dilakukan kontrol dan pengawasan dalam pemakaian gadget.

\section{Kenali anak kecanduan Gadget dan cara mengatasi}

Di era milenial seperti saat ini, pemandangan orang lalu lalang dengan menggunakan gadget bukanlah suatu hal yang aneh lagi. Mulai dari balita, anak sekolah hingga orang lanjut usia pasti sudah memiliki gadget. Banyak hal yang diuntungkan dengan adanya revolusi besar ini dalam kehidupan. Namun tak jarang efek negatif juga seringkali timbul dengan adanya gadget (Rahmawati, 2020).

Menggunakan gadget bukanlah suatu kesalahan, tapi jika sudah sampai kecanduan dan merugikan banyak pihak, sebaiknya perlu dilakukan tindakan mengurangi frekuensi pemakaian gadget. cara-cara yang harus dilakukan oleh orang tua ialah sebagai berikut :

\section{Pilih sesuai usia}

Dilihat dari tahapan perkembangan dan usia anak, pengenalan dan penggunaan gadget bisa dibagi ke beberapa tahap usia. Untuk anak usia di bawah 5 tahun, Pemberian gadget sebaiknya hanya seputar pengenalan warna, bentuk, dan suara. Artinya, jangan terlalu banyak memberikan kesempatan bermain gadget pada anak di bawah 5 tahun. Terlebih di usia ini, yang utama bukan gadget -nya, tapi fungsi orangtua. Pasalnya gadget hanya sebagai salah satu sarana untuk mengedukasi anak.

Ditinjau dari sisi neurofisiologis, otak anak berusia di bawah 5 tahun masih dalam taraf perkembangan. Perkembangan otak anak akan lebih optimal jika anak diberi rangsangan sensorik secara langsung. Misalnya, meraba benda, mendengar suara, berinteraksi dengan orang, dan sebagainya. Jika anak usia di bawah 5 tahun menggunakan gadget secara berkelanjutan, apalagi tidak didampingi orangtua, 
akibatnya anak hanya fokus ke gadget dan kurang berinteraksi dengan dunia luar(Marhaeni Pudji Astuti et al., 2018).

Yang berikutnya, otak bagian depan adalah bagian yang berfungsi memberi perintah dan menggerakkan anggota tubuh lainnya. Di bagian otak belakang, ada yang namanya penggerak(Marhaeni Pudji Astuti et al., 2018). Di bagian ini, terdapat hormon endorfin yang mengatur pusat kesenangan dan kenyamanan. Pada saat bermain gadget, anak akan merasakan kesenangan, sehingga memicu meningkatnya hormon endorfin. kecanduan berhubungan dengan ini jika dilakukan dalam jangka waktu lama dan kontinyu. Akibatnya, ke depannya, anak akan mencari kesenangan dengan jalan bermain gadget, karena memang sudah terpola sejak awal perkembangannya.

Dari aspek interaksi sosial, perkembangan anak-anak usia di bawah 5 tahun sebaiknya memang lebih ke arah sensor-motorik. Yaitu, anak harus bebas bergerak, berlari, meraih sesuatu, merasakan kasarhalus. Memang di gadget juga ada pengenalan warna atau games di mana orang melompat. Namun, kemampuan anak untuk berinteraksi secara langsung dengan objek nyata di dunia luar tidak diperoleh anak (Marpaung, 2018).

\section{Batasi waktu}

Anak usia di bawah 5 tahun, boleh-boleh saja diberi gadget. Tapi harus diperhatikan durasi pemakaiannya. Misalnya, boleh bermain tapi hanya setengah jam dan hanya pada saat senggang. Contohnya, kenalkan gadget seminggu sekali, misalnya hari Sabtu atau Minggu(Rahmawati, 2020). Lewat dari itu, ia harus tetap berinteraksi dengan orang lain. Aplikasi yang boleh dibuka pun sebaiknya aplikasi yang lebih ke fitur pengenalan warna, bentuk, dan suara.

Sejalan pertambahan usia, ketika anak masuk usia pra remaja, orangtua bisa memberi kebebasan yang lebih, karena anak usia ini juga perlu gadget untuk fungsi jaringan sosial mereka. Di atas usia 5 tahun (mulai 6 tahun sampai usia 10 tahun) orangtua bisa memperbanyak waktu anak bergaul dengan gadget. Di usia ini, anak sudah harus menggali informasi dari lingkungan. Jadi, kalau tadinya cuma seminggu sekali selama setengah jam dengan supervisi dari orangtua, kini setiap Sabtu dan Minggu selama dua jam. Boleh main games atau browsing mencari informasi. Intinya, kalau orang tua sudah menerapkan kedisiplinan sedari awal, maka di usia pra remaja, anak akan bisa menggunakan gadget secara bertanggungjawab dan tidak kecanduan gadget (Pebriana, 2017).

\section{Hindarkan kecanduan}

Kasus kecanduan atau penyalahgunaan gadget biasanya terjadi karena orangtua tidak mengontrol penggunaannya saat anak masih kecil. Maka sampai remaja pun ia akan melakukan cara pembelajaran yang sama. Akan susah mengubah karena kebiasaan ini sudah terbentuk. Ini sebabnya, 
orang tua harus ketat menerapkan aturan ke anak, tanpa harus bersikap otoriter(Siti Inayatul Ulya, 2019). Dan jangan lupa, orangtua harus menerapkan reward and punishment. Kalau ini berhasil dijalankan, maka anak akan bisa melakukannya secara bertanggungjawab dan terhindar dari kecanduan.

Ciri-ciri anak yang sudah kecanduan antara lain:

a. Anak menghabiskan sebagian besar waktunya untuk bermain dengan gadget.

b. Terobsesi. Anak menjadi marah, sedih, atau frustrasi kalau tidak bermain gadget. Saat orangtua menolak meminjamkan gadget, anak bisa naik pitam. Demikian juga, bila orangtua hendak mengambil gadget yang sedang dimainkan anak.

c. Anak mengabaikan/mengesampingkan kebutuhan lain hanya untuk bermian gadget. Misalnya lupa makan, lupa mandi.

d. Anak mengabaikan teguran-teguran dari orang sekitar (Amri, 2020)

\section{Beradaptasi dengan zaman}

Salah satu dampak positif gadget adalah akan membantu perkembangan fungsi adaptif seorang anak. Artinya kemampuan seseorang untuk bisa menyesuaikan diri dengan keadaan lingkungan sekitar dan perkembangan zaman. Jika perkembangan zaman sekarang muncul gadget, maka anak pun harus tahu cara menggunakannya.

Artinya fungsi adaptif anak berkembang. seorang anak harus tahu fungsi gadget dan harus bisa menggunakannya karena salah satu fungsi adaptif manusia zaman sekarang adalah harus mampu mengikuti perkembangan teknologi. Sebaliknya, anak yang tidak bisa mengikuti perkembangan teknologi bisa dikatakan fungsi adaptifnya tidak berkembang secara normal.Namun, fungsi adaptif juga harus menyesuaikan dengan budaya dan tempat seseorang tingga (Utamajaya et al., 2020).

\section{Kesimpulan}

Di zaman yang sangat modern pada saat ini perkembangan teknologi terus berkembang. Karena perkembangan teknologi akan berjalan sesuai perkembangan ilmu pengetahuan yang semakin tinggi. Teknologi diciptakan untuk memberikan kemudahan bagi kehidupan manusia dalam melakukan aktivitas sehari-hari dan memberikan nilai yang positif. Namun demikian, walaupun pada awalnya diciptakan untuk menghasilkan manfaat positif, di sisi lain juga memungkinkan digunakan untuk hal negatif. Berdasarkan pelaksanaan pengabdian masyarakat diperoleh hasil, sebagai berikut: 1). Penggunaan gadget yang berlebihan dapat menyebabkan menurunnya fokus belajar yang berakibat pada konsentrasi dan prestasi belajar. 2). Menimbulkan rasa malas, ketika diberi tugas oleh 
GANDRUNG: Jurnal Pengabdian Kepada Masyarakat ISSN: 2721-6136 (Online)

guru, siswa-siswi langsung membuka internet untuk mengakses jawaban dari soal tersebut. Tanpa di pikirkan terlebih dahulu kebanyakan para siswa-siswi langsung meng copy-paste jawaban yang sudah ada di internet. 3). Efek radiasi merupakan masalah yang buruk bagi kesehatan. Gadget mengandung zat radio aktif yang mampu berpindah ke suatu zat lain (tubuh manusia) tanpa melalui perantara. Jika pengguna setiap hari setiap waktu tidak pernah terlepas dengan gadget bukan tidak mungkin pengguna akan terkena radiasi, kanker otak, mengganggu kesehatan mental, dan kerusakan sel dalam tubuh merupakan efek dari radiasi. 4). Penggunaan gadget yang berlebihan juga mengakibatkan pemborosan. Semakin canggih gadget yang siswa-siswi miliki semakin banyak pengeluaran. Maka perlu ada tindak lanjut dalam pelatihan orang tua dalam mendampingi anak menggunakan gadget.

\section{Daftar Referensi}

Ariston, Y., \& Frahasini, F. (2018). Dampak Penggunaan Gadget Bagi Perkembangan Sosial Anak Sekolah Dasar. Journal Of Educational Review And Research, 1(2). Https://Doi.Org/10.26737/Jerr.V1i2.1675

Chusna, P. A. (2017). Pengaruh Media Gadget Pada Perkembangan Karakter Anak | Dinamika Penelitian: Media Komunikasi Penelitian Sosial Keagamaan. Dinamika Penelitian: Media Komunikasi Sosial Keagamaan, 17(2).

Frambach, J. M., Driessen, E. W., Beh, P., \& Van Der Vleuten, C. P. M. (2014). Quiet Or Questioning?

Students' Discussion Behaviors In Student-Centered Education Across Cultures. Studies In Higher Education. Https://Doi.Org/10.1080/03075079.2012.754865

Hikmaturrahmah, H. (2020). Dampak Penggunaan Gadget Pada Anak Usia Dini. Musawa: Journal For Gender Studies, 10(2). Https://Doi.Org/10.24239/Msw.V10i2.524

Jacob, P., \& Scott-Phillips, T. (2020). Is Mindreading A Gadget? Synthese. Https://Doi.Org/10.1007/S11229-020-02620-4

Marhaeni Pudji Astuti, T., Tri Atmaja, H., Utara, S., Singkawang, K., \& Barat, K. (2018). The Impact Of

The Use Of Gadgets In School Of School Age Towards Children's Social Behavior In Semata Village Article Info. Journal Of Educational Social Studies, 7(2).

Marpaung, J. (2018). Pengaruh Penggunaan Gadget Dalam Kehidupan. Kopasta: Jurnal Program Studi Bimbingan Konseling, 5(2). Https://Doi.Org/10.33373/Kop.V5i2.1521

Noviandari, H., \& Kawakib, J. (2016). Teknik Cognitive Restructuring Untuk Meningkatkan Self Efficacy Belajar Siswa. Jurnal Psikologi, 3(2). 
GANDRUNG: Jurnal Pengabdian Kepada Masyarakat ISSN: 2721-6136 (Online)

Noviandari, H., \& Mursidi, A. (2019). Relationship Of Self Concept, Problem Solving And Self Adjustment In Youth. International Journal For Educational And Vocational Studies, 1(6). Https://Doi.Org/10.29103/ljevs.V1i6.1599

Pebriana, P. H. (2017). Analisis Penggunaan Gadget Terhadap Kemampuan Interaksi Sosial Pada Anak Usia Dini. Jurnal Obsesi: Jurnal Pendidikan Anak Usia Dini, 1(1). Https://Doi.Org/10.31004/Obsesi.V1i1.26

Rahmawati, Z. D. (2020). Penggunaan Media Gadget Dalam Aktivitas Belajar Dan Pengaruhnya Terhadap Perilaku Anak. Ta"Lim : Jurnal Studi Pendidikan Islam, 3(1).

Rakhmawati, D., Ismah, I., \& Lestari, F. W. (2020). Sosialisasi Bahaya Kecanduan Gadget. Altruis: Journal Of Community Services, 1(3). Https://Doi.Org/10.22219/Altruis.V1i3.12926

Siti Inayatul Ulya. (2019). Analisis Penggunaan Gadget Terhadap Kemampuan Interaksi Sosial Dan Komunikasi Pada Anak Usia Dini. Seminar Nasional Paud.

Utamajaya, J. N., ; S. O. M., ; A. M., ; H. N., \& Bk, ; Muh. Khaerul Ummah. (2020). Investigating The Teaching Models, Strategies And Technological Innovations For Classroom Learning. Palarch's Journal Of Archaeology Of Egypt/Egyptology, 17(7). 